\title{
Mapping Out Gender Dynamics in Paddy Farming: A Case Study of Pavatkulam Major Irrigation Scheme in The Vavuniya District in Sri Lanka
}

\author{
T. Jeyaruba, S. De Silva ${ }^{1 *}$ and D.A.N. Dharmasena ${ }^{2}$ \\ Postgraduate Institute of Agriculture \\ University of Peradeniya \\ Sri Lanka
}

\begin{abstract}
Paddy cultivation is one of the main sources of livelihood, employment and contributors to human nutrition in the rural communities in Sri Lanka. Gender dynamics is an essential element of socio-economic analysis. This research, investigated the gender dynamics in paddy cultivation of three major ethnic communities namely, Sinhala, Tamil and Muslim, in a selected major irrigation scheme in the Vavuniya district. A total number of 156 farm families, including 63 Sinhalese, 63 Tamil and 30 Muslim, were proportionately and randomly selected through stratified sampling technique. A combination of Participatory Rural Appraisal (PRA) tools and a questionnaire survey were used to collect data during Maha season 2010/2011. Among the three communities, household reproductive (nonincome generating) activities were mostly done by females (93\%). Land assets were owned mostly by males (62\%), and almost all the machineries were also owned by male family members, thus giving them the access and control over the resources. Both males and females were involved in decision-making related to household activities (81\%). However, in all three communities, the major decisions regarding paddy cultivation were either made or influenced by males. The involvement of males in paddy cultivation was higher (71\%) than the females in the three communities. In the Sinhala community, involvement of females in paddy cultivation was one-and-a-half and three times higher in comparison to the involvement of females in Tamil and Muslim communities, respectively. Females in the Muslim community got hardly engaged in any field work in paddy cultivation due to their cultural norms. In all three communities, females were placed in an important position in the family to attend to the nutrition, hygiene, childcare, health and education (non-income generating tasks) in comparison to their male counterparts. However, with regard to productive tasks (paddy farming) there were considerable gender differences with regard to ownership and control of resources, decision-making power and involvement in different activities, placing females in a disadvantageous position.
\end{abstract}

Keywords: Ethnicity, gender, household activities, irrigation, paddy farming

Department of Agricultural Extension, Faculty of Agriculture, University of Peradeniya, Sri Lanka Department of Agricultural Engineering, Faculty of Agriculture, University of Peradeniya, Sri Lanka Corresponding author: saliyalk@yahoo.com 


\section{INTRODUCTION}

Sri Lanka, like other countries in the Asian region has an agricultural economy, and the agricultural sector plays an important role in socioeconomic development of the country. In this respect, paddy farming is a major source of livelihood, nutrition, and employment (Tilakaratna, 2003; Mendis and Udomsade, 2005). The agricultural sector continues to be one of the main contributors to the Sri Lankan economy and its share in Gross Domestic Product (GDP) was $11.9 \%$ in 2010, growth by $7.0 \%$ compared with $3.2 \%$ in 2009 (Central Bank of Sri Lanka, 2011). Paddy contributed 1.7\% to the GDP in 2009 and $1.8 \%$ in 2010 (Central Bank of Sri Lanka, 2011).

Each farming system has its own distinct characteristics and the working patterns of farming communities are governed by various socioeconomic and cultural dimensions that affect gender roles, responsibilities and division of labour (Grover and Sethi, 2007). Gender relations are influenced by ethnicity, age, religion, marital status, traditions, ideologies, perceptions of a society as well as cultural and economic conditions (Danso et al., 2004).

Agricultural activities are found to be clearly gender segregated: pesticide application/dusting, spade work during field irrigation, ploughing, sowing, manuring and fertilizer application, and marketing of grains are mostly performed by males. All over the world, rural females have traditionally played, and continue to play, an important role in both rice production and postharvest activities. Transplanting and storage of grains are mostly done by females. Other farm activities such as weeding, harvesting, carrying loads, threshing and winnowing are performed jointly by females and males, but predominantly by females (Food and Agriculture Organization, 2004).

Over the years, labour scarcity for agricultural activities has gradually become a serious problem (Wanasundera, 2006; Tilakaratne and Somaratne, 2002).Labour involvement in paddy production is of national interest as the cost of production is at an increasing trend. The percentage share of labour in the total cost ranged from $65 \%$ in the Kandy District to $35 \%$ in Ampara-East. The lower percentage of labour cost in Hambantota, Ampara-East, Mannar and Ampara-West is due to the use of combine harvesters (Department of Agriculture, 2011). In the hilly areas, machinery use is limited due to terrace cultivation on slopes. The total man days per acre ranged from 28 to 34 in all districts of Sri Lanka except in Kandy, Hambantota, Ampara-East, Mannar and Ampara-West. Kandy district has reported the highest man days per acre requirement (46) due to the practice of transplanting (Department of Agriculture, 2011). Although, both males and females work as the labourers in paddy farming, their involvement is influenced by many socioeconomic and cultural factors at present (Molen, 2001). In the labour market, unequal pay, occupational exclusion or segregation into low-skill and low-paid work are the factors limiting females' earnings in comparison to those of males of similar education levels. Commonly, females' earnings ranged from 50-85\% of males' (Reeves and Baden, 2000). Especially in the North East as elsewhere in Sri Lanka, females' wages were much lower than males (Wanasundera, 2006; Tilakaratne and Somaratne, 2002). Without an improvement in the rural economy, women's wages will continue to stagnate due to the imbalance of labour supply over its demand. For instance, in Kanthasinnakulam DS Division in the Vavuniya District of Sri Lanka, females earned between Rs.80-100 a day for harvesting paddy whereas males got Rs.200 in the year 2006. A male's labour was valued at twice the value of a female's labour (Wanasundera, 2006). 
Mapping out gender dynamics, an essential element of socioeconomic analysis; refers to the variety of methods used to understand the relationships between males and females, their access to resources, their activities, and the constraints they face relative to each other. Although females play an important role in paddy production, their contribution is unrevealed and/or undervalued, as reflected by low wage rates paid to them. Gender activists even argue that the workload of the females engaged in paddy production (i.e. total energy spent) is greater than males, since they are also involved in most of domestic chores. However, the involvement of males and females in paddy framing depends on the type of farming activity, region or locality, ethnic group and many other factors. Therefore, the objective of this research was to investigate the gender dynamics in paddy cultivation in different ethnic communities in a selected major irrigation scheme in the Vavuniya district, Sri Lanka.

\section{METHODOLOGY}

Pavatkulam irrigation scheme in Vavunia district provides livelihood to all three main communities; Sinhalese, Tamils and Muslims. These people are involved in either fulltime or part-time paddy cultivation. The farmers in this settlement had been given 0.6 ha $(1.5 \mathrm{ac})$ of highland and 1.2 ha ( $3 \mathrm{ac}$ ) of lowland (Paddy land) by the government in 1957.

A total number of 156 farm families, 63 Sinhalese, 63 Tamil and 30 Muslim were proportionately and randomly selected using a stratified sampling technique. The sample size was determined based on the total number of families in each ethnic group live in the settlement. Table 1 gives the details of the communities, extents of cultivation, total number of farm families and their family members who are engaged in agriculture.

Table 1. Demographic information of the study area

\begin{tabular}{llccc}
\hline Division & Community & $\begin{array}{c}\text { Cultivation } \\
\text { land ( ac) }\end{array}$ & $\begin{array}{l}\text { No. of farm } \\
\text { families }\end{array}$ & $\begin{array}{l}\text { Total No. of } \\
\text { members in } \\
\text { farm families }\end{array}$ \\
\hline Unit 1 & Tamil & 330 & 110 & 480 \\
Unit 2 & Muslim & 303 & 214 & 1372 \\
Unit 3 & Sinhala & 540 & 280 & 765 \\
Unit 4 & Tamil & 573 & 145 & 672 \\
Unit 5 & Tamil & 294 & 98 & 378 \\
Unit 6 & Tamil & 288 & 85 & 365 \\
Purana & Sinhala & 577 & 284 & 1249 \\
Acre 20,40,60 & Sinhala & 237 & 80 & 276 \\
Acre 400 & Sinhala & 300 & 134 & 561 \\
Unit 9 and 10 & Tamil & 692 & 296 & 976 \\
Total & & 4134 & 1726 & 7094 \\
\hline
\end{tabular}

Source: Vavuniya Statistical Hand Book, 2010

A combination of Participatory Rural Appraisal (PRA) tools and a questionnaire survey were used to collect data during 2010/2011 Maha season. PRA tools used were mapping out daily routine activities of males and females, seasonal calendar, focused group discussions, Key Informant Interview (KII) as well as observations and informal interviews. The survey was conducted based on a semi-structured questionnaire, which contained information on general 
issues, household work, community work and paddy cultivation activities. Data were analyzed using SPSS (Statistical Package for the Social Sciences) package. Descriptive statistics were used for data analysis in SPSS package. Under the descriptive statistics, frequencies, descriptive and crosstab tools were used for this analysis. Chi Square test was used for significant testing.

\section{RESULTS AND DISCUSSION}

\section{Gender differences in household activities}

All three communities live within a patriarchal structure. Table 2 gives the reproductive tasks (non-income generating) of a typical paddy farming family of the sample. It reveals that among the three communities, household reproductive activities such as collecting water, cooking, washing clothes, childcare and general cleaning are done mostly by females, while $69 \%$ involved in collecting firewood are males. Among the reproductive work, females spend most of their time in the kitchen, preparing meals for their families. It must be noted that females are solely responsible for the nutrition, hygiene, health and sanitary needs of the families in the study area.

Table 3 provides the time share of each gender on reproductive work. According to findings, females spend an average of about 10h/day for reproductive tasks, while males spend an average of only $1.4 \mathrm{~h} /$ day for reproductive tasks (Table 3 ).

Table 2. Reproductive tasks of a typical family

\begin{tabular}{|c|c|c|c|c|c|}
\hline \multirow{2}{*}{ Activity } & \multicolumn{2}{|c|}{$\begin{array}{r}\text { Engagement of } \\
\text { gender } \\
(\%)\end{array}$} & \multicolumn{2}{|c|}{$\begin{array}{r}\text { Time taken to complete } \\
\text { the task (min/day) }\end{array}$} & \multirow{2}{*}{$\begin{array}{r}\text { Frequency of } \\
\text { involvement } \\
(\text { per week })\end{array}$} \\
\hline & Male & Female & Average & Maximum & \\
\hline Collecting water & 1 & 99 & 41 & 90 & 22 \\
\hline Collecting firewood & 69 & 31 & 90 & 180 & 2 \\
\hline Cooking & 0 & 100 & 187 & 240 & 18 \\
\hline Bathing children & 0 & 100 & 41 & 60 & 7 \\
\hline Feeding children & 0 & 100 & 48 & 120 & 21 \\
\hline Teaching children & 14 & 86 & 59 & 120 & 7 \\
\hline Washing utensils & 0 & 100 & 53 & 90 & 15 \\
\hline Washing clothes & 0 & 100 & 54 & 90 & 7 \\
\hline House cleaning & 0 & 100 & 37 & 60 & 17 \\
\hline Washing toilets & 0 & 100 & 24 & 30 & 3 \\
\hline $\begin{array}{l}\text { Attending to children's } \\
\text { health }\end{array}$ & 3 & 97 & 11 & 20 & 6 \\
\hline $\begin{array}{l}\text { Cleaning the surrounding } \\
\text { area }\end{array}$ & 1 & 99 & 20 & 30 & 5 \\
\hline
\end{tabular}

Source: Field Survey 2010 - 2011 
Table 3. Time spent on reproductive work (hours per week)

\begin{tabular}{lcc}
\hline Country & Female & Male \\
\hline United States of America & 27 & 16 \\
Switzerland & 33 & 24 \\
Japan & 29 & 4 \\
Developing countries & $31-42$ & $5-15$ \\
Sri Lanka (Pavatkulam Irrigation Scheme) & 68 & 10 \\
\hline Source: United Nations, 2010 and Field Survey 2010 - 2011 & &
\end{tabular}

Females spending more time on domestic work than their male counterparts are not only common in Sri Lanka, but also in other developed and developing countries (Table 3). In developed regions, females spend an average of five hours a day on domestic work, whereas males spend average less than two and a half hours a day (UN, 2010). In Italy, Japan, Portugal and Spain for instance, females spend three to four fold the amount of time spent by males on domestic work. In both Latin America and Africa, females spend far more than twice the time males spend on unpaid domestic work. Females in developed countries spend less time on domestic work in comparison to those in the developing countries, and especially rural areas of Sri Lanka, due to the availability of modern household equipment, food habits, different food preparation methods, etc. Therefore, female have limited time to engage in income-generating activities or leisure time activities such as engage in hobbies and entertainment. . Most of the family's income is earned by the male counterpart. Females are expected to collect water, prepare food/cooking, feed and take care of children and be responsible for the family's health. Females are also involved in the educational activities of the children and guide them towards future careers. Therefore, a female is considered to be an important person in the household sector. She is expected to accomplish various and multi-tasks, and is thought to be a key person in the household. However, with the growing cost of living, females are also compelled to carry the economic burden despite their involvement in the reproductive tasks.

Unfortunately, the non-cash earning nature of domestic tasks is not calculated in national income terms and therefore, a female's services to her family are not valued at the national income accounts (e.g. GDP). Therefore, females are unpaid and unrecognized in the socioeconomic development of the country although they play a main role towards the prosperity of families and communities. Therefore, it is vital that females engaged in domestic work be given importance and their work valued at the national level.

\section{Income generating activities within the homestead}

Most of the females are engaged in income-generating activities within the homestead in addition to their reproductive work in all three communities (Table 4). When considering the overall income generating activities within the homestead, females engagement is $83 \%$ and male involvement is only $17 \%$, mainly because males are involved in paddy cultivation activities. The average time spent on income generating activities within the homestead mostly by women is $4.6 \mathrm{~h} /$ day. Therefore, females work on average of up to $14.6 \mathrm{~h} /$ day on reproductive and income generating activities within the homestead. It was revealed that, although males help their female counterparts in livestock management and home gardening work during the off season, they do not help females in their reproductive work. Further, during the paddy cultivation season, most of the females have to work for long hours due to their involvement in paddy farming. 
Table 4. Income generating activities within homestead

\begin{tabular}{lcccccc}
\hline Activity & $\begin{array}{r}\text { Family } \\
\text { involvement } \\
(\boldsymbol{\%})\end{array}$ & $\begin{array}{r}\text { Gender } \\
\text { involvement } \\
(\boldsymbol{\%})\end{array}$ & Time taken (min/day) & $\begin{array}{r}\text { Frequency } \\
\text { of } \\
\text { Male }\end{array}$ & $\begin{array}{r}\text { Female } \\
\text { involvement } \\
\text { (per week) }\end{array}$ \\
\hline $\begin{array}{l}\text { Home } \\
\text { gardening }\end{array}$ & 82 & 21 & 79 & 121 & 300 & 7 \\
$\begin{array}{l}\text { Livestock } \\
\text { Cottage }\end{array}$ & 71 & 22 & 78 & 70 & 240 & 16 \\
business & 7 & 9 & 91 & 153 & 300 & 4 \\
\hline Source: Field Survey $2010-2011$ & & & & & &
\end{tabular}

Source: Field Survey $2010-2011$

\section{Access to and control over the resources}

\section{Land assets}

It was evident that in all three communities most of the land assets are owned by males (62\%), thus giving them the access and control over it (Table 5). Consequently, since females have less or limited access to land resources they at a disadvantageous position, when decisions are made with regard to allocation of water, memberships in farmer organizations, dissemination of information, application for cultivation and investment loans etc. Even when the females hold the ownership, in most cases, the control over the land is with their male counterparts.

Table 5. Percentage of gender based land ownership among three communities

\begin{tabular}{lccc}
\hline Ethnicity & Male & Female & Both \\
\hline Highland & 52 & 48 & 0 \\
Sinhalese & 57 & 43 & 0 \\
Tamil & 59 & 41 & 0 \\
Muslim & & & \\
Paddy land & 61 & 33 & 6 \\
Sinhalese & 56 & 40 & 4 \\
Tamil & 55 & 45 & 0 \\
Muslim & & 36 & \\
Other high land & 64 & 32 & 0 \\
Sinhalese & 68 & 14 & 0 \\
Tamil & 86 & 37 & 0 \\
Muslim & 62 & & 1 \\
Average & & & \\
\hline Sirce:F & & & \\
\hline
\end{tabular}

Source: Field Survey $2010-2011$

Chi Square test was used to measure the relationship between ethnicity and male and female ownership of highlands and paddy lands. Results indicated that there is no statistically significant relationship between the ethnicity and gender based ownership of highland $\left(\mathrm{X}^{2}=\right.$ $0.508, P=0.776)$; paddy land $\left(X^{2}=2.137, P=0.711\right)$, and other highlands $\left(X^{2}=1.197, P=\right.$ $0.550)$. 


\section{Machinery}

In addition to land, most of the machinery ( $4 \mathrm{~W}$ tractor, $2 \mathrm{~W}$ tractor and thresher, etc) are also owned by the male members (almost $100 \%$ ) due to high value investments in machinery and it is the males who usually handle them (Table 6). and In Sri Lanka machinery usage are restricted to males and there is also a general perception that women are incompetent in that field.

Table 6. Ownership of machinery (\%)

\begin{tabular}{lcc}
\hline Machinery & Male & Female \\
\hline 4-Wheel tractor & 100 & 0 \\
Sinhalese & 100 & 0 \\
Tamil & 100 & 0 \\
Muslim & & \\
2-Wheel tractor & 100 & 0 \\
Sinhalese & 100 & 0 \\
Tamil & 100 & 0 \\
Muslim & & \\
Thresher & 100 & 0 \\
Sinhalese & 100 & 0 \\
Tamil & 0 & 0 \\
Muslim & & \\
Sprayer & 97 & 3 \\
Sinhalese & 98 & 2 \\
Tamil & 100 & 0 \\
Muslim & & \\
\hline
\end{tabular}

Source: Field Survey $2010-2011$

\section{Decision making power}

Table 7 shows decision making power related to household activities and paddy farming. In most cases, both males and females are involved in decision making related to household activities $(81 \%)$. Females have a slightly higher share in household decision making than males as they are believed to have more knowledge and experience with regard to care, education, health and nutrition of children and other household activities. During a critical situation, females propose ideas to males and males make the final decision. Within the "Patriarchal" system and the attitudes of male "bread winners" in Sri Lanka, it is common that major decisions are made or influenced by males.

Chi Square test was used to analyze the relationship between ethnicity and decision making power in household activities. Results revealed that there is a significant relationship between the ethnicity and decision making power in household activities $\left(X^{2}=12.93\right.$, $\mathrm{P}<0.01)$. Further, there is a statistically significant relationship between the ethnicity and decision making power in paddy farming activities $\left(\mathrm{X}^{2}=39.07, \mathrm{P}<0.01\right)$ as well.

In the Sinhala community, both male and female (83\%) are involved in decision making related to paddy cultivation, and this is nearly two thirds and three times higher than that of the Tamil and Muslim communities, respectively. However, in other two communities, involvement of women in decision making is relatively poor and males having considerable 
amount of decision making power. However, in all three communities, the major decisions are either taken or influenced by males in paddy cultivation similar to critical household decision making.

Table 7. Nature of decision making power (\%) on household activities and paddy farming

\begin{tabular}{lccc}
\hline Ethnicity & Male & Female & Both \\
\hline Household activity & 5 & & \\
Sinhalese & 14 & 9 & 86 \\
Tamil & 10 & 19 & 67 \\
Muslim & 10 & 0 & 90 \\
Overall & & & 81 \\
Paddy farming & 11 & 6 & 83 \\
Sinhalese & 43 & 9 & 48 \\
Tamil & 73 & 0 & 27 \\
Muslim & 42 & 5 & 53 \\
Overall & & & \\
\hline
\end{tabular}

Source: Field Survey $2010-2011$

\section{Gender differences in paddy cultivation activities}

Paddy cultivation is divided into 22 main activities (Refer to the notes given in Table 8). There are various factors affecting the engagement of females in paddy cultivation, e.g. family and cultural tradition, family type, household responsibilities, economic status, marital status, type of husbands' job, husbands' wishes, ages of children, number of dependents in a family and distance to the fields etc. Table 8 reveals that the involvement of males in paddy cultivation is higher $(71 \%)$ than females among all the three communities. Female engagement is more in preparation of paddy for sowing, transplanting, gap filling, harvesting, and bundle making and carrying, and carrying meals and tea to the field. In the Sinhala community, involvement of females in paddy cultivation is one and half and three times higher in comparison to the involvement of females in Tamil and Muslim communities, respectively. Females in the Muslim community hardly engage in any field paddy cultivation activities due to their cultural norms.

It was also revealed during focus group discussions and interviews that, a higher percentage of females in the Sinhala community engage in paddy cultivation in comparison to the Tamil and Muslim communities as $65 \%$ males of the Sinhala community are part-time paddy farmers and most of them are employed as home guards by the government. This necessitates the females to complete their household duties and also be involved in paddy cultivation. In the Tamil community, most of the farmers (76\%) are engaged in full-time basis, enabling the females to be involved in full-time domestic activities. When required by husbands, these females engage in paddy cultivation after completing their household responsibilities. They also go to the field to work whenever they get free time from their domestic chores.

According to the Muslim culture and religion, as revealed in a focus group discussion, females are not allowed to interact with males other than their fathers, husbands or brothers. As per their culture, females are not much involved in paddy cultivation. However those who are very poor and low economic status are involved in paddy cultivation with their husbands. It is also very rare to see poor Muslim females or widows working in the field as outside (hired) labourers. In the Muslim community, females even don't go to the mosque at prayer 
times (except on festival days), instead they pray at home. Their custom requires females to stay at home. Younger women face more restrictions in venturing outside their homes.

Table 8. Gender differences of paddy farming activities (\% involvement)

\begin{tabular}{crrrrrr}
\hline \multirow{2}{*}{ Activity } & \multicolumn{2}{c}{ Sinhalese } & \multicolumn{3}{c}{ Tamil } & \multicolumn{3}{c}{ Muslim } \\
\cline { 2 - 7 } 1 & Male & Female & Male & Female & Male & Female \\
2 & 58.9 & 41.1 & 83.7 & 16.3 & 97.6 & 2.4 \\
3 & 70.7 & 29.3 & 100.0 & 0.0 & 96.9 & 3.1 \\
4 & 100.0 & 0.0 & 100.0 & 0.0 & 100.0 & 0.0 \\
5 & 58.8 & 41.2 & 98.8 & 1.2 & 97.1 & 2.9 \\
6 & 71.7 & 28.3 & 98.8 & 1.2 & 97.3 & 2.7 \\
7 & 46.4 & 53.6 & 48.4 & 51.6 & 50.0 & 50.0 \\
8 & 100.0 & 0.0 & 100.0 & 0.0 & 100.0 & 0.0 \\
9 & 0.0 & 0.0 & 66.7 & 33.3 & 0.0 & 0.0 \\
10 & 0.0 & 0.0 & 0.0 & 100.0 & 0.0 & 0.0 \\
11 & 26.7 & 73.3 & 34.9 & 65.1 & 0.0 & 100.0 \\
12 & 55.4 & 44.6 & 88.3 & 11.7 & 90.7 & 9.3 \\
13 & 65.2 & 34.8 & 94.9 & 5.1 & 100.0 & 0.0 \\
14 & 92.8 & 7.2 & 100.0 & 0.0 & 100.0 & 0.0 \\
15 & 91.4 & 8.6 & 100.0 & 0.0 & 100.0 & 0.0 \\
16 & 81.0 & 19.0 & 100.0 & 0.0 & 100.0 & 0.0 \\
17 & 50.4 & 49.6 & 67.2 & 32.8 & 91.3 & 8.7 \\
18 & 53.1 & 46.9 & 71.2 & 28.8 & 92.6 & 7.4 \\
19 & 100.0 & 0.0 & 100.0 & 0.0 & 0.0 & 0.0 \\
20 & 0.0 & 0.0 & 0.0 & 0.0 & 0.0 & 0.0 \\
21 & 91.1 & 8.9 & 100.0 & 0.0 & 100.0 & 0.0 \\
22 & 89.2 & 10.8 & 100.0 & 0.0 & 100.0 & 0.0 \\
\hline 1 & 53.9 & 46.1 & 65.5 & 34.5 & 89.7 & 10.3 \\
\hline
\end{tabular}

Source: Field Survey $2010-2011$

Notes: Activity 1-branch irrigation channel cleaning, 2-bund making, 3-ploughing and levelling by machines, 4hand levelling, 5-making drainage system, 6-preparation of paddy for sowing, 7-sowing seeds, 8-nursery preparation, 9-transplanting, 10-gap filling, 11-irrigation, 12-carrying the inputs to the field (seed paddy, fertilizer and pesticides etc.), 13-applying weedicides, 14-applying pesticides, 15-applying fertilizer, 16-manual harvesting, 17-making bundles and carrying the bundles to thresher, 18-threshing, 19-harvesting by combine harvester, 20packaging, 21-transporting to home and 22-carrying meals and tea to the field .

The concept of the male breadwinner and female housewife has changed over time due to the socioeconomic changes. Earlier it was perceived that females should not go out for paid work. However, currently females are playing not only the roles of housewife and mother but also as an income earner. Females have to look for income generating activities as supplementary income because of the family economic burden, leaving females on a higher work load than males. When females are engaged as family labour in the field (Table 8), whether regular or seasonal, they are unpaid and are, therefore, rarely taken into account in official statistics.

It is obvious that females are overworked due to taking care of household chores in addition to helping the farming and other income generating activities with their spouses. They spend many hours of working, losing energy and time for rest and recreation. This could cause 
serious socioeconomic and health problems in the long run, which may influence negatively on the family unit and income generation. Therefore, greater attention needs to be paid on sharing the household chores between males and females in the farming communities, in such a way that both parties are not over burdened with work load or responsibilities.

\section{CONCLUSION}

Gender relations in paddy cultivation are governed by the socioeconomic and cultural dimensions and it affects gender roles, responsibilities, and division of work. In all three communities, there are considerable gender imbalance with regard to household activities, income generating activities within homestead, ownership and control of resources, decision making power and involvement in different activities in paddy cultivation. This could result in negative socioeconomic and health impacts. However, further investigation would be necessary to generalize the findings for the whole country and other industries.

\section{ACKNOWLEDGEMENT}

Authors wish to acknowledge Crossing Boundaries Project of the Postgraduate Institute of Agriculture, University of Peradeniya, funded by the Government of Netherlands and implemented by SaciWATERs, India for providing financial assistance to conduct the research. Farm families of the three communities for their support and cooperation during the field survey are also appreciated.

\section{REFERENCES}

Central Bank of Sri Lanka (2011). Annual Report 2010. Government of Sri Lanka.

Danso, G., Cofie, O., Annang, L., Obuobie, E. and Keraita, B. (2004). Gender and

Urban agriculture: The Case of Accra, Ghana. Paper presented at the RUAF/IWMI/ Urban Harvest Woman Feeding Cities Workshop on Gender Main Streaming in Urban Food Production and Food Security. 20-23 September, Accra, Ghana.

Department of Agriculture, Peradeniya. (2011). Cost of Cultivation of Agricultural Crops 2009/2010 Maha. Volume 58. pp. 13-44

Food and Agriculture Organization of the United Nation. (2004). Food and Population [on line] [Accessed on 10.10.2010]. Available at www.fao.org

Grover, I. and Sethi, N. (2007). Mapping out gender dynamics of farming systems of Haryana. Journal of Social Science. 14(3), 281-288.

Mendis, I.U. and Udomsade, J. (2005). Factors affecting adoption of recommended crop management practices in paddy cultivation in Kalutara district, Sri Lanka. Kasetsart.J (Soc.Sci) 26, 91-102.

Molen, I. (2001). An Assessment of Female Participation in Minor Irrigation Systems of Sri Lanka. The Technology and Development Group, University of Twente, Enschede, the Netherlands and International Water Management Institute. pp. 5- 32 
Reeves, H. and Baden, S. (2000). Gender and Development: Concepts and Definitions. Report 55. Prepared for the Department for International Development (DFID) for its Gender Mainstreaming Intranet Resource.

Tilakaratna, H.M. (2003). Country Report- Sri Lanka. Technical Advisory Committee meeting, 13th -14th December, Hanoi, Vietnam.

Tilakaratne, I.G. and Somaratne, H.M. (2002). Strategies to Overcome the Scarcity of Agricultural Labour: An Empirical Study of a Rural Village in the Dry zone. Annual of the Sri Lanka Department of Agriculture.4, 399-406.

United Nation (2010). The world women 2010-Trends and statistics [on line] [Accessed on 06.10.2011]. Available at http://unstats.un.org/unsd/demographic/produ.

Vavuniya Statistical Hand Book, 2010. District Planning Secretariat, District Secretariat, Vavuniya.

Wanasundera, L. (2006). Rural Women in Sri Lanka's Post Conflict Rural Economy. Rap Publication- 13. pp. 7- 43. 